\title{
Acardiac acephalus with malformed donor twin
}

\section{Shruti Panchbudhe*, Meena Satia, Lalita Kambhampatti}

Department of Obstetrics and Gynaecology, Seth Gordhandas Sunderdas Medical College and King Edward VII Memorial Hospital, Mumbai, Maharashtra, India

Received: 16 June 2016

Accepted: 06 July 2016

\section{*Correspondence:}

Dr. Shruti Panchbudhe,

E-mail: shrutipanchbudhe@gmail.com

Copyright: ( ) the author(s), publisher and licensee Medip Academy. This is an open-access article distributed under the terms of the Creative Commons Attribution Non-Commercial License, which permits unrestricted non-commercial use, distribution, and reproduction in any medium, provided the original work is properly cited.

\section{ABSTRACT}

Some specific cases of Acardiac twins observed in remote parts of India where foetuses have been found to have extra limbs jutting out of chest cavity or abdomen have been given the specific and an attractive name of god baby. The present case under discussion is one such case where an Acardiac twin with Acephalus in the parasitic twin and malformed donor twin with multiple congenital anomalies incompatible with life delivered spontaneously at a tertiary care centre.

Keywords: Acardiac twins, Acephalus, Parasitic twin

\section{INTRODUCTION}

Acardiac twins is a result of TRAP i.e. Twin reversed arterial perfusion seen in $1 \%$ of monochorionic twin gestation where one twin is structurally normal called the donor twin and a recipient twin which receives all its blood supply from the donor twin through its vascular connections on the surface of the placenta. ${ }^{1}$ Twin Reversed Arterial Perfusion sequence also called TRAP sequence, TRAPS, or Acardiac twinning is a rare complication of monochorionic twin pregnancies. Acardiac twins has an incidence of 1 in 35000 pregnancies and it is a severe variant of twin-to-twin transfusion syndrome (TTTS). ${ }^{1}$ In the recent years times the incidence has been reported to be higher which is probably attributed to assisted reproductive techniques which lead to an increase in multiple pregnancies and early detection by more and more first trimester ultrasound examinations. The Acardiac twin or TRAP fetus, is severely malformed with a missing or deformed heart, hence the name Acardiac, and the other twin is usually normal in appearance. The normal twin, called the donor twin, drives blood through both foetuses. It is called reversed arterial perfusion because in the Acardiac twin the blood flows in a reversed direction which leads to decreased growth of the upper torso and near normal growth of the lower parts. ${ }^{2}$ Because the disorder is monozygotic, the twins are usually of same gender and females are usually more affected than the males. Early diagnosis and high clinical suspicion can offer treatment options like selective reduction of the parasitic twin in utero, allowing the donor twin to grow normally.

\section{CASE REPORT}

21 year old female, married since 3 years, Gravida 2, Para1, Living1, came to the outpatient department for antenatal registration. She was 25 weeks of gestation by dates and 27 weeks of gestation by scan and she had an outside ultrasonography report suggestive of polyhydramnios of $29.5 \mathrm{~cm}$ and omphaocoele of $4 \times 4 \mathrm{~cm}$ size. On examination patient was found to be 30 weeks per abdomen, with cephalic presentation and polyhydramnios without an appreciable fetal heart sound. Foetal viability scan showed live fetus. Patient was admitted for further evaluation. Her antenatal profile comprising of Haemoglobin $9.2 \mathrm{~g} / \mathrm{dl}$, Blood group was a positive, HIV, Hepatitis B surface antigen and VDRL were negative and she had received 2 doses of Tetanus toxoid injection. After admission her Oral glucose challenge test done for evaluating the cause of polyhydramnios in which the values were fasting, 1 hour and 2 hour values were 73, 93, $99 \mathrm{mg}$ respectively, all of which were normal. She underwent a malformation scan at our tertiary care institution which showed a $4 \mathrm{~cm} \mathrm{x} 4 \mathrm{~cm}$ sized defect in the anterior abdominal wall with 
herniation of liver and right kidney and few bowel loops suggestive of omphaocoele, congenital diaphragmatic hernia and complex heart anomaly. In view of the above findings she was advised fetal 2D echo which showed omphaocoele with right congenital diaphragmatic hernia with double outlet right ventricle with hypoplastic left heart, probable pulmonary atresia and early hydropic changes. Paediatric surgery reference was taken in view of above findings and poor fetal prognosis was explained to the patient and relatives. Patient was discharged after this evaluation and was readmitted when she presented to the emergency room in active labour at 31 weeks gestation. On Per abdomen examination uterus was 32 weeks, with polyhydramnios with cephalic presentation and fetal heart sounds were not heard and she was getting a uterine activity of $2 / 10 / 25$. On vaginal examination she was $3 \mathrm{~cm}$ dilated, $40 \%$ effacement of cervix, vertex presenting part, membranes were present and pelvis was adequate. Her scan was done which was suggestive of intrauterine fetal demise. DIC profile was done which showed INR 1.04, APTT 28.5, control 26, fibrinogen 438, FDP > 320 and D Dimer 5.5. Patient progressed well and delivered a Female baby of $2.1 \mathrm{~kg}$ which was found to have a parasitic Acephalic Acardiac twin attached at the level of thorax to the donor twin with fully formed legs, left arm and a rudimentary right arm. The donor twins were born with omphaocoele, malformed right arm, and malformed ears and diffuse soft tissue oedema. There was a single placenta and monochorionicity was confirmed on histopathology. This anomaly was however missed on ultrasonography.

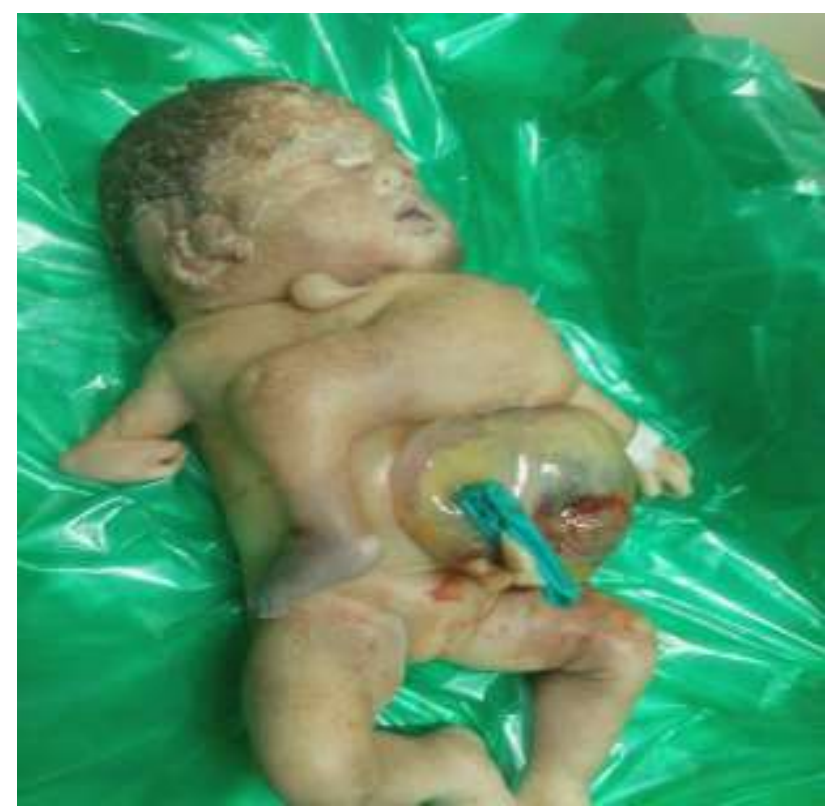

Figure 1: Acardiac acephalus with malformed donor twin.

\section{DISCUSSION}

Twin reversed arterial perfusion sequence (TRAP) is a rare and unique complication of monochorionic twin pregnancy in which a twin with no heart or with a heart which is a non-functioning ("Acardiac twin") is being perfused by its co-twin called as "donor twin" due to placental arterial anastomoses. The Acardiac twin most often has a poorly developed heart, upper body, and head. Acardiac twins can be one of four types depending on level of organ formation. Acephalus is the most common form with an absent head and absent thoracic organs but with reasonably well developed arms and legs. ${ }^{3}$ The second variety is Anceps has almost all body parts but with an incomplete brain and crudely formed organs. The third variety is Acormus has no distinct body and disorganised organ tissue could be found in the apparent head and sometimes parts of limbs could be seen.

Amorphous is the last variety and extreme form with no body parts or even tissue organization. In the TRAP sequence, most of the times a normally formed twin who is the donor twin has signs and symptoms of heart failure and a recipient twin that lacks a heart (Acardius) and other structures. The TRAP sequence is caused by a large artery-to-artery placental shunt, which is often also accompanied by a vein-to-vein shunt. The arterial perfusion pressure of the donor is higher than the recipient twin who receives deoxygenated arterial blood from its cotwin. This "used" arterial blood reaches the recipient twin via its umbilical arteries which selectively goes to its iliac vessels which results in perfusion of the lower part of the body and disrupted growth and development of the upper body. Due to this vascular connection, the normal donor twin has to maintain dual perfusion, to support not only its own circulation but also of the Acardiac recipient which results in cardiomegaly and high-output heart failure in the normal twin. This unequal vascular perfusion leads to the most common presentation of Acardiac Acephalus where head and upper body are not formed. The donor twin itself can have other congenital anomalies in about $9 \%$ of cases as is seen in our present case. ${ }^{4}$

The donor twin has a perinatal mortality rate of $55-55 \%$ usually due to premature delivery because of polyhydramnios or secondary to congestive cardiac failure. ${ }^{5}$ Early ultrasound examination from 5-6 weeks of gestation demonstrates 2 fetal heart sounds, that combined with reversal of blood flow through umbilical cord of the fetus suggest that the primary pathogenesis of Acardia is dysmorphogenesis which is due to reversal of blood flow rather than primary cardiac agenesis. ${ }^{6}$ TRAP sequence can be confirmed by Doppler examination documenting the reversal of flow.

Management of Acardiac twins can be expectant or interventional. According to a study by Sullivan et al expectant management should be considered in all cases as studies clearly indicate that more than half the pregnancies complicated by Acardiac twins result in a live born donor twin without the need for any prenatal intervention. $^{7}$ Termination of pregnancy should be considered if acardiac twinning is diagnosed early in the 
pregnancy. Expectant or interventional approach is to be determined by serial ultrasound and Doppler surveillance and echocardiography. ${ }^{8}$ Prenatal intervention should be considered in large Acardiac twin, polyhydramnios, abnormal Doppler such as persistent absent or reversed diastolic flow in the umbilical artery, pulsatile flow in the umbilical vein and ductus venosus showing reversed flow, hydrops fetalis in donor twin and monochorionicmonoamniotic twins. The poly-hydraminos which is most commonly seen with this condition can be treated either by medications or by amnioreduction, definitive treatment modalities that cause occlusion of the perfused (acardiac) twin's cord or rudimentary aorta may be achieved by a variety of fetoscopic or ultrasound guided techniques (intrafetal laser ablation, radiofrequency thermal ablation and fetoscopic cord occlu sion with absolute alcohol, platinum coils, thermogenic coils). ${ }^{9-12}$ As described in literature with careful case selection improved outcome for the donor twin may be up to $85 \%$. $^{13}$

Most significant complications include cotwin demise or decreased cerebral blood flow and/or preterm ruptured membranes. The relative weight of acardiac twins is an indicator of prognosis. Conservative treatment is best reserved for salvation of the pump twin when the acardiac twin is less than one quarter the weight of the pump twin and there are no signs of impending heart failure.14 Invasive intervention is usually reserved for cases in which the acardiac twin exceeds $70 \%$ of that of the pump twin but however, the prognosis in these cases appears to be poor. However the most appropriate interventions for various clinical presentation of this disorder are yet to be determined and conservative non-interventional techniques are usually better. Also the data on surviving donor twins are lacking and more research is needed in this area. In our present case report, had the diagnosis been picked up on ultrasonography nothing active intervention could have been done as the donor twin was malformed with a Acardiac Acephalus, however termination could have been offered if the patient would have presented before 20 weeks.

Funding: No funding sources

Conflict of interest: None declared

Ethical approval: Not required

\section{REFERENCES}

1. Sogaard K, Skibsted L, Brocks V. Acardiac twins: pathophysiology, diagnosis, outcome and treatment.
Six cases and review of the literature. Fetal Diagn Therapy. 1999;14:53-9.

2. Hanafy A, Peterson CM. Twin-reversed arterial perfusion (TRAP) sequence: case reports and review of literature. Aust NZJ Obstet Gynaecol. 1997;37:187-91.

3. Chen CP, Shih SL, Liu FF. Skeletal deformities of acardius anceps: The gross and imaging features. Pediatr Radiol. 1997;27:221-5.

4. Barth RA, Crow HC. Ultrasound evaluation of multifetal gestation. In: Callen PW, editor. Callen ultrasonography in obstetrics and gynaecology. 4th ed. Pennsylvania: W B Saunders; 2000. pp. 196-8.

5. Bornstein E, Monteagudo A, Dong R. Detection of twin reversed arterial perfusion sequence at the time of first-trimester screening: the added value of 3dimensional volume and colour Doppler sonography. J Ultrasound Med. 2008;27:1105.

6. Sullivan AE, Varner MW, Ball RH, Jackson M, Silver RM. The management of acardiac twins: a conservative approach. Am J Obstet Gynecol. 2003;189:1310-31.

7. Egan JF, Borgida AF. Ultrasound evaluation of multiple pregnancies. In: Callen PW, editor. Ultrasonography in obstetrics and gynecology. 5th ed. Pennsylvania: W B Saunders; 2008. pp. 286-8.

8. Rodeck C, Deans A, Jauniaux E. Thermocoagulation for the early treatment of pregnancy with an acardiac twin. N Engl J Med. 1998;339:1293-5.

9. Soothill P, Sohan K, Carroll S, Kyle P. Ultrasoundguided, intraabdominal laser to treat acardiac pregnancies. BJOG. 2002;109:352-4.

10. Tsao K, Feldstein VA, Albanese CT, Sandberg PL, Lee H, Harrison MR, Farmer DL. Selective reduction of acardiac twin by radiofrequency ablation. Am J Obstet Gynecol. 2002;187:635-40.

11. Tongsong T, Wanapirak C, Sirichotiyakul S, Chanprapaph P. Intrauterine treatment for an acardiac twin with alcohol injection into the umbilical artery. J Obstet Gynaecol Res. 2002;28:769.

12. Lee $\mathrm{H}$, Wagner AJ, Sy E, Ball R. Efficacy of radiofrequency ablation in management of TRAP. Am J Obstet Gynecol. 2007;196:459e1-4.

13. O’Donoghue K, Barigye O, Pasquini L, Chappell L, Wimalasundera RC, Fisk NM. Interstitial laser therapy for fetal reduction in monochorionic multiple pregnancy: loss rate and associated with aplasia cutis congenital. Prenat Diagn. 2008;28:535-43.

14. Weisz B, Peltz R, Chayen B. Tailored management of twin reversed arterial perfusion (TRAP) sequence. Ultrasound Obstet Gynecol. 2004;23:451-5.

Cite this article as: Panchbudhe $S$, Satia $M$,

Kambhampatti L. Acardiac acephalus with malformed donor twin. Int J Reprod Contracept Obstet Gynecol 2016;5:2872-4. 